\title{
Annoyance due to aircraft noise has increased over the years-Results of the HYENA study
}

\author{
Wolfgang Babisch a,*, Danny Houthuijs ${ }^{\mathrm{b}}$, Göran Pershagen ${ }^{\mathrm{c}}$, Ennio Cadum ${ }^{\mathrm{d}}$, Klea Katsouyanni ${ }^{\mathrm{e}}$, \\ Manolis Velonakis ${ }^{\mathrm{f}}$, Marie-Louise Dudley ${ }^{\mathrm{g}}$, Heinz-Dieter Marohn ${ }^{\mathrm{a}}$, Wim Swart ${ }^{\mathrm{b}}$, Oscar Breugelmans ${ }^{\mathrm{b}}$, \\ Gösta Bluhm ${ }^{\text {c }}$, Jenny Selander ${ }^{\text {c }}$, Federica Vigna-Taglianti ${ }^{\mathrm{d}}$, Salvatore Pisani ${ }^{\mathrm{h}}$, Alexandros Haralabidis ${ }^{\mathrm{e}}$, \\ Konstantina Dimakopoulou ${ }^{e}$, Ioannis Zachos ${ }^{f}$, Lars Järup ${ }^{c, g}$ \\ and HYENA Consortium
}

\footnotetext{
a Federal Environment Agency (UBA), Corrensplatz 1, Berlin, 14195, Germany

b The National Institute for Public Health and the Environment (RIVM), PO Box 1, Bilthoven, 3720 B A, The Netherlands

' Karolinska Institute, Box 210, Stockholm, 17177, Sweden

d Piedmont Regional Environmental Protection Agency, Via Sabaudia 164, Grugliasco (TO), 10095, Italy

e University of Athens, 75 Mikras Asias St, Athens, 11527, Greece

${ }^{\mathrm{f}}$ University of Athens, 123 Papadiamadopoulou St, Athens, 11527, Greece

' Imperial College London, Norfolk Place, London, W2 1PG, United Kingdom

${ }^{n}$ U. O. Osservatorio Statistico-Epidemiologico, Via Ottorino Rossi 9, 21100 Varese, Italy
}

\section{A R T I C L E I N F O}

\section{Article history:}

Received 11 May 2009

Accepted 23 July 2009

Available online xxxx

\section{Keywords:}

Aircraft noise

Road traffic noise

Annoyance

Exposure-response curve

Change of annoyance

\begin{abstract}
A B S T R A C T
In the HYENA study (HYpertension and Exposure to Noise near Airports) noise annoyances due to aircraft and road traffic noise were assessed in subjects that lived in the vicinity of 6 major European airports using the 11-point ICBEN scale (International Commission on Biological Effects of Noise). A distinction was made between the annoyance during the day and during the night. $L_{\mathrm{den}}$ and $L_{\text {night }}$ were considered as indicators of noise exposure. Pooled data analyses showed clear exposure-response relationships between the noise level and the noise annoyance for both exposures. The exposure-response curves for road noise were congruent with the EU standard curves used for predicting the number of highly noise annoyed subjects in European communities. Annoyance ratings due to aircraft noise, however, were higher than predicted by the EU standard curves. The data supports other findings suggesting that the people's attitude towards aircraft noise has changed over the years, and that the EU standard curve for aircraft noise should be modified.
\end{abstract}

(c) 2009 Elsevier Ltd. All rights reserved.

\section{Introduction}

The association between noise and noise annoyance has been extensively investigated. Annoyance is a term used in general for all negative feelings such as disturbance, dissatisfaction, displeasure, irritation, and nuisance (Guski, 1999; Ouis, 2002). Pooled analyses (meta-analyses) were carried out and synthesis curves were derived that can be used for the prediction of the percentage of annoyed subjects (Miedema and Vos, 1998; Schultz, 1978). A distinction has been made between the percentages of 'little annoyed' (\%LA), 'annoyed' (\%A) and 'highly annoyed' (\%HA) subjects according to certain cut-off criteria of the distributions of annoyance ratings in the individual studies (Miedema and Oudshoorn, 2001). Conversions were made with respect to the noise indicator $L_{\mathrm{den}}$ according to the

\footnotetext{
* Corresponding author. Tel.: +49 308903 1370; fax: +49 3089031830 . E-mail address: wolfgang.babisch@uba.de (W. Babisch).
}

EU Directive on Environmental Noise (Directive 2002/49/EC, 2002). The curves derived by Miedema et al. (known as 'Miedema curves') are commonly used for predicting the number of highly noise annoyed subjects in European communities (European Commission Working Group on Dose-Effect Relations, 2002). Similar exposureresponse relationships were derived with respect to self-reported sleep disturbance by a European Commission working group (European Commission Working Group on Health and SocioEconomic Aspects, 2004; Miedema and Vos, 2007). A common finding in the syntheses of annoyance and sleep disturbance studies was that at the same A-weighted average noise exposure level or noise indicator, aircraft noise was more annoying than road traffic noise, and railway noise less annoying than road traffic noise (Fields and Walker, 1982; Kryter, 1982; Kryter, 1983; Miedema and Vos, 1998). As well as other reasons, shielding (non-exposed side of the house) and access to quiet rooms may have an impact on the annoyance ratings, which could be a possible explanation for the observed source-specific differences of annoyance curves (e. g. aircraft noise vs. road traffic noise) (Jakovljevic et al., 2009; Kryter, 1982; Miedema and 
Borst, 2007; Schultz, 1982). The American standard ANSI 12.9 part 4, which is based on ISO 1996-using different correction factors-does not consider a railway bonus, and the penalty for aircraft noise varies between 0 and $5 \mathrm{~dB}$, depending on the sound level (ANSI S12.9, 2003; Gjestland, 2008; ISO 1996/1, 2003). The present article is concerned with the possible change of the peoples' perception of aircraft noise throughout the years.

In some newer investigations annoyance ratings due to aircraft noise were found to be higher than predicted by the EU standard curve (Kastka et al., 1995; Le Masurier et al., 2007; Schreckenberg and Meis, 2006, 2007). Time-selective meta-analyses suggested that annoyance exposure-response relationships might be moving upwards (Guski, 2003; Guski, 2004; van Kempen and van Kamp, 2005; Wirth et al., 2005a). It has been suggested that the perception of aircraft noise and the attitude towards it-and thus the annoyancehas changed over the years (Bröer and Wirth, 2004). This may be due to the fact that many of the studies that were considered for the exposure-response curves are now more than 25 years old. During the 1960s through to the 1990s the sound level equivalent causing $25 \%$ of 'highly annoyed' subjects due to aircraft noise seemed to have diminished by approximately 6-7 $\mathrm{dB}(\mathrm{A})$ of the $L_{\mathrm{DN}}$ (Bröer and Wirth, 2004; Guski, 2004). However, methodological factors of studies such as response rate could also have played a role (selection bias). Particularly, in telephone surveys and postal questionnaire surveys, higher annoyance ratings were found with increasing response rate, suggesting that less annoyed subjects are less likely to participate in social surveys on community noise annoyance (Brooker, 2009). Annoyance is a multi-factorial concept that is only partly determined by the noise level (Fields, 1993; Guski, 1999; Job, 1988a, 1991; Job and Hatfield, 1998; Miedema and Vos, 1999; Öhrström et al., 1988; Ouis, 2001). Although clear exposure-response relationships have been found between the noise level and the noise annoyance, the amount of variance $\left(R^{2}\right)$ that is explained by the noise level is relatively small (25 to 30\%) (van Kempen et al., 2005; Kroesen et al., 2008).

In the HYENA study we assessed noise levels and annoyances due to aircraft noise and road traffic noise in large population samples in the vicinity of six major European airports. We compared the relationships between road traffic noise level and annoyance due to road traffic noise on the one hand, and the association between aircraft noise level and annoyance due to aircraft noise on the other, with the EU standard annoyance curves for both noise sources. Possible derivations of the HYENA curves from the EU aircraft noise curve could be viewed relative to HYENA derivations from the EU road traffic noise curve. Because both refer to the same subjects we were able to see whether the relationship between noise and noise annoyance had changed in general or source specifically. In other words, we could use the relationships for road traffic noise as a reference for the judgement upon any change of the annoyance due to aircraft noise curve from the respective EU exposure-response curve.

\section{Methods}

The HYENA study (HYENA = HYpertension and Exposure to Noise near Airports) is a large-scale multi-centred study carried out simultaneously in 6 European countries to assess the relationship between aircraft noise and road traffic noise on the one hand, and the prevalence of high blood pressure on the other. Details regarding the study design were given elsewhere (Jarup et al., 2005, 2008). The present article is concerned with the association between noise and noise annoyance. Annoyance due to different noise sources was assessed in a similar way at the same time in different airports/countries.

\subsection{Study sample}

The study population included 4861 people (2404 men and 2467 women) aged between 45 and 70 years at the time of interview, and who had been living for at least 5 years, near one of six major European airports (London-Heathrow (GB), Berlin-Tegel (D), Amsterdam-Schiphol (NL), Stockholm-Arlanda (S), Milan-Malpensa (I) and Athens-Elephtherios Venizelos (GR)). In Stockholm, also the citizens living near the City Airport (Bromma) were included to increase the number of exposed subjects. Subjects were selected at random from available registers (e.g. registration office, electoral roll, health service). To maximise exposure contrast, the population was stratified using existing noise contours. Areas with other sources of noise exposure (rail, industry, etc.) were largely excluded. Field work was carried out between 2003 and 2005.

\subsection{Noise level}

To facilitate comparability between the HYENA countries, the 'Integrated Noise Model' (INM) served as the standard model for the assessment of the aircraft noise exposure based upon radar flight tracks (Gulding et al., 2002). For aircraft noise $L_{\text {day, } 12 \mathrm{~h}}, L_{\text {evening, } 4 \mathrm{~h}}$ and $L_{\text {night,8 }}$ here calculated (day defined as the hours from 7:00 to 19:00 or 6:00 to $18: 00$, evening defined as the hours from 19:00 to 23:00 or 18:00 to 22:00 and night defined as the hours from 23:00 to 7:00 or 22:00 to 6:00, according to the 'European Environmental Noise Directive' (Directive 2002/49/EC, 2002)). In the UK the model 'Ancon' was applied which fulfills the requirements of the European Civil Aviation Conference (European Civil Aviation Conference, 1997). Road traffic noise assessment was based on available noise data according to the national assessment methods (United Kingdom: Calculation of Road Traffic Noise (Department for Transport and Welsh Office, 1988); Germany, Italy: Richtlinien für den Lärmschutz an Straßen (Bundesministerium für Verkehr (Ministry of Transport), 1990); Greece, The Netherlands: Standaard Rekenen Meetvoorschrift (SRM) (Ministry of Housing Spatial Planning and the Environment, 2002); Sweden: Nordic Prediction Method (Bendtsen, 1999)) and the 'Good Practice Guide for Strategic Noise Mapping' (Directive 2002/49/EC, 2002; European Commission Working Group Assessment of Exposure to Noise (WG-AEN), 2006).

All noise levels were modelled for 2002; this year was assumed to be representative for the five-year period preceding the health assessment. Modelled noise exposure levels were linked to each participant's home address (most exposed façade) using geographic information systems (GIS) technique. The special resolution (grid size) was $250 \times 250 \mathrm{~m}$ for aircraft and $10 \times 10$ for road traffic noise. For both aircraft and road traffic noise the levels had a $1 \mathrm{~dB}$ resolution, except for the UK where only $5 \mathrm{~dB}$ classes for road traffic noise could be procured. The midpoints of these classes were chosen for the analyses using continuous exposure data. $L_{\mathrm{den}}$ and $L_{\text {night }}$ were calculated for both aircraft and road traffic noise according to the 'European Environmental Noise Directive', considering $+5 \mathrm{~dB}(\mathrm{~A})$ and $+10 \mathrm{~dB}(\mathrm{~A})$ weighing factors for the evening and night period, respectively (Directive 2002/49/EC, 2002). Approximations were used to calculate $L_{\mathrm{den}}$, when only $L_{\text {Aeq, } 24 \mathrm{~h}}$ (considering a $10 \mathrm{~dB}(\mathrm{~A})$ difference between $L_{\mathrm{day}, 16 \mathrm{~h}}$ and $L_{\text {night }}$ ) or $L_{\mathrm{day}, 16 \mathrm{~h}}$ and $L_{\text {night }}$ (considering a $2 \mathrm{~dB}(\mathrm{~A})$ difference between $L_{\mathrm{day}, 16 \mathrm{~h}}$ and $L_{\mathrm{den}}$ ) were available for road traffic noise (Bite and Bite, 2004; European Commission Working Group Assessment of Exposure to Noise (WGAEN), 2006). To minimize the impact of inaccuracies on the noise levels at the lower end, cut-off values of $40 \mathrm{~dB}(\mathrm{~A})$ for $L_{\mathrm{den}}$ and of $30 \mathrm{~dB}(\mathrm{~A})$ for $L_{\text {night }}$ were introduced for aircraft noise. The lower cut-off level for road traffic noise were set to $45 \mathrm{~dB}(\mathrm{~A})$ and $35 \mathrm{~dB}(\mathrm{~A})$, respectively.

Based on information about number of movements and-where available-noise monitoring data, it was found that aircraft noise exposure had not changed considerably between 2002 (the year in which the noise contours were modelled) and the years when the field work was carried out (annoyance assessment). With respect to road traffic noise, it was very unlikely that major changes had occurred during this time-considering that doubling/halving of the traffic volume results in (only) $\mathrm{a}+/-3 \mathrm{~dB}$ change of the noise level. 
Furthermore, the magnitudes of the correlation between the noise level and the annoyance were found to be similar as in other annoyance studies (see Results section).

\subsection{Noise annoyance}

During the home visits personal interviews were carried out (faceto-face interview). The standardised questionnaire consisted of questions regarding health status, socio-demographic, lifestyle and behavioral factors, annoyance and personality factors including noise sensitivity. Noise annoyance was assessed using the non-verbal 11point 'ICBEN scale' (Fields et al., 2001), because verbal translations were only available in English, German and Dutch. The Greek, Swedish and Italian partners of HYENA had to make their own translations. This was done carefully by the partners using back- and forward translation. Native English speakers were involved, and existing material in the partner countries was considered for the translation process. The battery of annoyance items referred to air traffic, road traffic and other community noise or indoor noise sources (e.g. railway, motorcycles, industry, construction, neighbours and indoor installations). A distinction was made between source-specific noise annoyances during the day and the night, and between the global noise annoyance with open and closed windows. In the statistical analyses average noise scores were used, as well as percentages above certain cut-off levels of the annoyance scale for comparisons (percent highly annoyed $=\% \mathrm{HA}$, categories $8,9,10$ on the 11 point scale (range: 0 to 10) (European Commission Working Group on Dose-Effect Relations, 2002). This cut-off criterion of $72.7 \%$ approximates the $71-$ $73 \%$ criterion used by Schulz and Miedema for converted scales which are ranging from 0 to 100 (Miedema and Oudshoorn, 2001; Schultz, 1978). In fact, the combination of ratings 8,9,10 of the 11-point ICBEN scale underestimates the \%HA slightly compared to the EU curve. (Note: the combination of the categories 4 and 5 of the 5 -point verbal ICBEN scale-on the other hand-overestimates the \%HA).

\subsection{Non-acoustical factors}

As part of the interview, personality and behavioral factors were assessed, including noise sensitivity (10 items, 6 point Weinstein scale, sum score) (Stansfeld and Shine, 1993). Noise sensitivity is a personality factor that is theoretically independent of the noise exposure (Job, 1999; Stansfeld, 1992). It is an independent predictor of annoyance (van Kamp et al., 2004). Attitude towards the airport was assessed to identify differences between airports ("What is your attitude towards your local airport?", 11 point scale: $0=$ very negative to $10=$ very positive) (van Kamp, 1990). It is associated with the noise exposure and the annoyance.

\section{Results}

Aircraft noise, road traffic noise and motorcycles were the most dominant sources of noise annoyance in our sample. The mean annoyance ratings (day/night) on the 11 point scale (range: $0-10)$ were as follows: aircraft $(4.57 / 3.08)$, road $(2.53 / 1.50)$, train $(0.38 / 0.28)$, motorcycles $(2.18 / 1.20)$, tram $(0.02 / 0.00)$, construction $(0.85 / 0.06)$, neighbours $(0.84 / 0.51)$, industry $(0.37 / 0.16)$, shops $(0.19 / 0.25)$, indoor $(0.30 / 0.17)$. In

\section{Table 2}

Average noise exposure (mean, standard deviation) stratified by country.

\begin{tabular}{|c|c|c|c|c|c|}
\hline \multirow[t]{2}{*}{ Country } & \multicolumn{2}{|c|}{$L_{\mathrm{den}}[(\mathrm{dB}(\mathrm{A})]$} & \multirow[t]{2}{*}{ Country } & \multicolumn{2}{|c|}{$L_{\text {night }}[\mathrm{dB}(\mathrm{A})]$} \\
\hline & Air & Road & & $\overline{\text { Air }}$ & Road \\
\hline$\overline{\mathrm{GB}}$ & $59.5(9.7)$ & $55.0(5.4)$ & GB & $49.3(10.6)$ & $47.1(5.5)$ \\
\hline $\mathrm{D}$ & $52.2(10.4)$ & $59.6(8.8)$ & D & $40.2(10.0)$ & $50.5(9.2)$ \\
\hline NL & $55.7(6.5)$ & $56.8(7.7)$ & NL & $42.2(8.9)$ & $48.6(7.9)$ \\
\hline$S$ & $53.7(7.0)$ & $52.7(6.1)$ & S & 39.5 (7.9) & $43.4(6.2)$ \\
\hline I & $48.3(8.5)$ & $57.5(10.2)$ & I & $34.8(6.1)$ & $48.1(10.5)$ \\
\hline GR & $53.8(6.3)$ & $49.3(6.5)$ & GR & $41.8(4.6)$ & $40.2(7.1)$ \\
\hline Total & $53.7(8.8)$ & $55.4(8.4)$ & Total & $40.9(9.2)$ & $46.6(8.7)$ \\
\hline
\end{tabular}

the following, the focus is on aircraft and road traffic noise only, which were also objectively assessed (noise level). Table 1 shows the distribution of the noise levels $L_{\mathrm{den}}$ and $L_{\text {night }}$ for aircraft and road traffic noise (categorical data). Due to the stratified sampling frame reasonable numbers were achieved in each noise category. Nonparametric correlation coefficients between $L_{\mathrm{den}}$ and $L_{\text {night }}$ (continuous data with cutoff set at low noise levels) were $r_{\mathrm{s}}=0.88$ (air) and $r_{\mathrm{s}}=0.99$ (road); correlation coefficients between aircraft and road traffic noise levels were $r_{\mathrm{s}}=0.01\left(L_{\mathrm{den}}\right)$ and $r_{\mathrm{s}}=0.03\left(L_{\text {night }}\right)$, indicating that the two noises were very independent of one another. The mean differences between $L_{\mathrm{den}}$ and $L_{\text {night }}$ were $12.8 \mathrm{~dB}(\mathrm{~A})$ for aircraft noise and $8.8 \mathrm{~dB}(\mathrm{~A})$ for road traffic noise. Table 2 shows the average noise exposure (mean and standard deviation) of the subjects stratified by airport [country]. London-Heathrow (GB) and Amsterdam-Schiphol (NL) subjects were most, and Milan-Malpensa (I) subjects least exposed to aircraft noise. Berlin-Tegel (D) subjects were most, and Athens-Elephtherios Venizelos (GR) and Stockholm-Arlanda/Bromma (S) subjects least exposed to road traffic noise. (Note: These figures are not representative for the population in each area. They only reflect the sampling frames of each centre).

Table 3 shows the percentage of 'highly annoyed' subjects stratified by airport [country] ('highly annoyed' refers to the categories 8,9, and 10 on the 11 point scale). Athens-Elephtherios Venizelos (GR) and London-Heathrow (GB) subjects were most, and Amsterdam-Schiphol (NL) subjects least annoyed by aircraft noise. MilanMalpensa (I) and Berlin-Tegel (D) subjects were most, and Athens-Elephtherios Venizelos (GR) and Stockholm-Arlanda/Bromma (S) subjects least annoyed by road traffic noise. Non-parametric correlation coefficients between day and night annoyance scores were $r_{\mathrm{s}}=0.68$ (aircraft) and $r_{\mathrm{s}}=0.65$ (road); correlation coefficients between aircraft and road traffic noise annoyance were $r_{\mathrm{s}}=0.22$ (day) and $r_{\mathrm{s}}=0.27$ (night). The results indicate that both annoyances were independent of one another. By trend, age was negatively associated with annoyance within the age range of the study sample (47-70 years). However, the effect was significant only with respect to road traffic noise during the night.

Figs. 1 and 2 show the relationships between aircraft noise and road traffic noise $\left(L_{\mathrm{den}}\right)$ and the percentages of highly annoyed subjects due to aircraft and road traffic noise during the day for the country-specific samples. For comparison, the EU curves of 'highly' annoyed subjects (\%HA) are also shown in the graphs (light circles). Figs. 3 and 4 show the relationships between aircraft noise and road traffic noise $\left(L_{\text {night }}\right)$ and the percentages of highly annoyed subjects due to aircraft and road traffic noise during the night for the country-specific samples. For comparison, the EU curves of 'highly' (subjectively) sleep disturbed subjects (\%HA) are also shown in the graphs. To enable visual comparisons, the range of the annoyance scale is kept constant in all graphs. While the country-specific annoyance ratings of road traffic noise scatter around the EU curve (Figs. 2 and 4), the ratings of aircraft annoyance are all higher than predicted by the EU curve (Figs. 1 and 3). A considerable heterogeneity between the airports is obvious. Particularly, subjects from the Greece (Athens) and Italy (Mailan) airports were much more annoyed by aircraft noise than subjects from the other 4 airports. This was not found with respect to road traffic noise.

As expected, attitude towards the airport was negatively associated with the aircraft noise level in all subsamples $(p<0.001)$. To see whether there were major differences between the countries, the attitude towards the airport of subjects from the reference category $\left(L_{\mathrm{den}}<45 \mathrm{~dB}(\mathrm{~A})\right)$ and subjects from the highest categories of aircraft noise $\left(L_{\mathrm{den}} \geq 60 \mathrm{~dB}(\mathrm{~A})\right.$ ) were compared between countries (Note: the subjects were differentially distributed over the noise categories at each airport.). Figs. 5 and 6 show the boxplots of the attitude towards the airport in each country for these subgroups.
Table 1

Distribution of noise levels.

\begin{tabular}{|c|c|c|c|c|c|}
\hline \multirow{2}{*}{$\begin{array}{l}\text { Noise level } \\
{[\mathrm{dB}(\mathrm{A})]}\end{array}$} & \multicolumn{2}{|c|}{ Frequency [\%] } & \multirow{2}{*}{$\begin{array}{l}\text { Noise level } \\
{[\mathrm{dB}(\mathrm{A})]}\end{array}$} & \multicolumn{2}{|c|}{ Frequency [\%] } \\
\hline & $L_{\mathrm{den}}-\mathrm{air}$ & $L_{\text {den-road }}$ & & $L_{\text {night-air }}$ & $L_{\text {night }}$-road \\
\hline$\overline{<45}$ & 23.6 & 15.2 & $<35$ & 36.5 & 13.8 \\
\hline $45-49.9$ & 7.8 & 14.9 & $35-39.9$ & 14.1 & 12.2 \\
\hline $50-54.9$ & 13.7 & 20.6 & $40-44.9$ & 12.7 & 19.1 \\
\hline $55-59.9$ & 29.7 & 19.9 & $45-49.9$ & 16.7 & 20.0 \\
\hline $60-64.9$ & 17.2 & 12.9 & $50-54.9$ & 12.3 & 15.2 \\
\hline $65-69.9$ & 8.0 & 9.9 & 55-59.9 & 7.6 & 16.6 \\
\hline$\geq 70$ & - & 6.6 & $\geq 60$ & - & 9.1 \\
\hline
\end{tabular}

Table 3

Percentage of 'highly annoyed' subjects stratified by country.

\begin{tabular}{|c|c|c|c|c|c|}
\hline \multirow[t]{2}{*}{ Country } & \multicolumn{2}{|l|}{ Day } & \multirow[t]{2}{*}{ Country } & \multicolumn{2}{|l|}{ Night } \\
\hline & \%HA-air & \%HA-road & & \%HA-air & \%HA-road \\
\hline GB & 35.8 & 14.3 & GB & 31.7 & 10.5 \\
\hline $\mathrm{D}$ & 22.3 & 16.6 & D & 14.6 & 9.9 \\
\hline NL & 18.1 & 8.4 & NL & 11.2 & 5.7 \\
\hline S & 24.5 & 5.9 & $S$ & 8.9 & 2.2 \\
\hline I & 27.8 & 21.5 & I & 18.0 & 9.7 \\
\hline GR & 52.8 & 4.6 & GR & 37.6 & 2.7 \\
\hline Total & 28.5 & 11.8 & Total & 18.4 & 6.6 \\
\hline
\end{tabular}




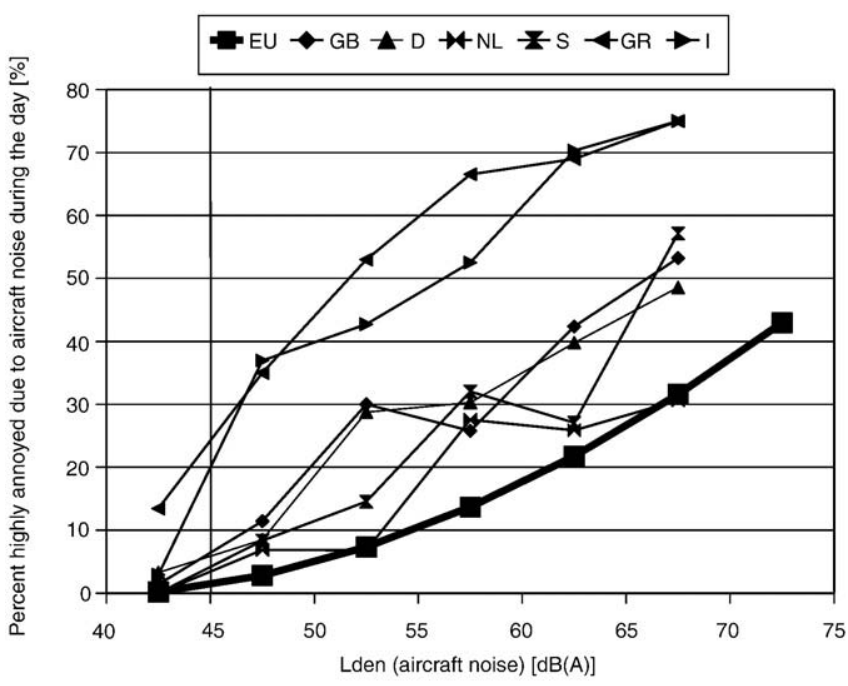

Fig. 1. Relationships between aircraft noise ( $L_{\mathrm{den}}$-air) and annoyance due to aircraft noise during the day (EU and country-specific curves). Note: The EU curve is defined for noise levels from 45 to $75 \mathrm{~dB}(\mathrm{~A})$.

The most negative rating of the airport was found in the Athens (GR) and Milan (I) samples, the most positive ratings were found in the Amsterdam (NL) and Stockholm (S) samples.

Participation rates differed between the countries, from not less than $30 \%$ in Germany, Italy and the UK, to $46 \%$ in the Netherlands, 56\% in Greece and 78\% in Sweden. The low response rate in some countries could have been a potential source of bias because aircraft noise annoyed subjects are maybe more inclined to participate in a noise study (Franssen et al., 2004). If noise annoyance was a motivating factor affecting the willingness to participate, one would expect a higher response rate in more noise exposed areas. Based on geo-code information, the exposure to aircraft noise was compared between responders and non-responders. No significant differences were found in London-Heathrow, Berlin-Tegel, Amsterdam-Schiphol, Stockholm-Arlanda/ Bromma. In Athens-Eleftherios Venizelos the response rate was higher in subjects exposed to more aircraft noise, whereas the opposite was found in Milan-Malpensa (lower participation rate in exposed areas). No major differences were found between responders and non-responders with respect to age, gender in any of the samples. In Berlin and Amsterdam additional information regarding the year when the subjects moved into their dwellings was available from the registry offices. No significant difference between responders and non-responders was found. Full details about the non-responder assessment can be taken from the major technical report prepared for the EU (Jarup, 2007).

To assess further possible selection bias, we looked at the distribution of the subjects' noise sensitivity across noise level categories and by country. Since noise sensitivity is a personality factor that was found to be independent of the exposure, its

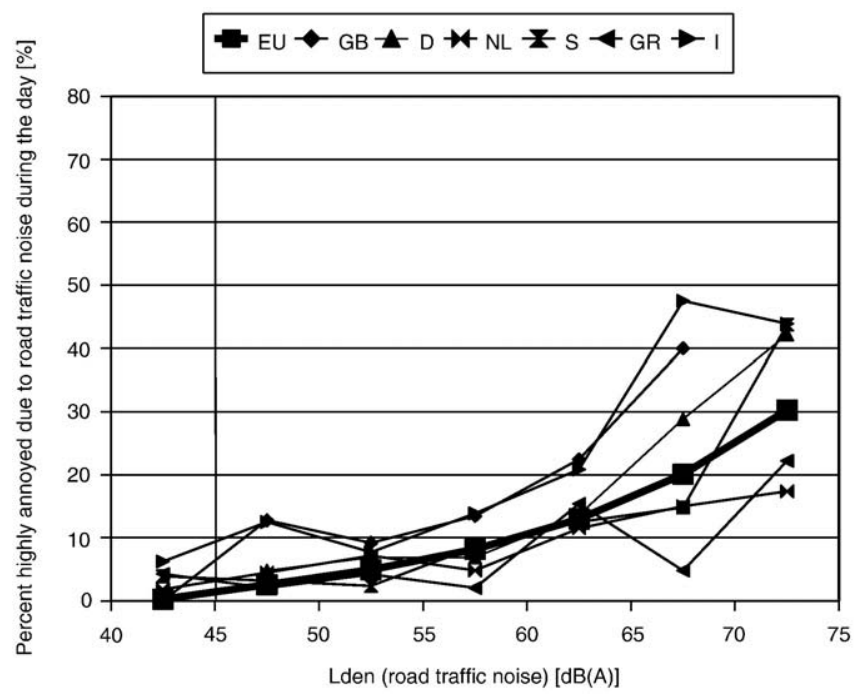

Fig. 2. Relationships between road traffic noise $\left(L_{\mathrm{den}}\right.$-road) and annoyance due to road traffic noise during the day (EU and country-specific curves).

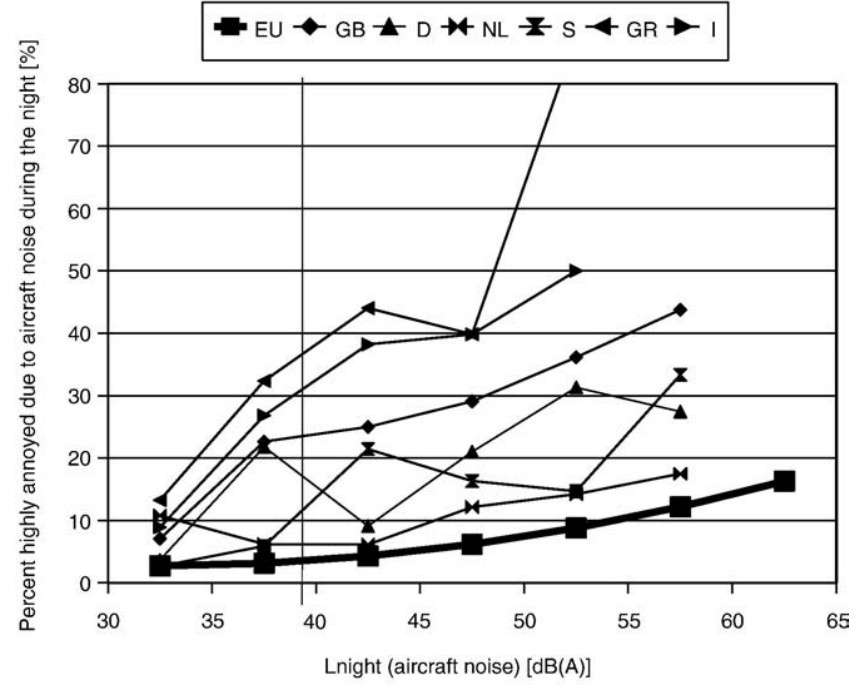

Fig. 3. Relationships between aircraft noise ( $L_{\text {night }}$-air) and annoyance due to aircraft noise during the night (EU and country-specific curves). Note: The EU curve is defined for noise levels from 40 to $70 \mathrm{~dB}(\mathrm{~A})$.

prevalence may be an indicator of potential selection bias. Fig. 7 shows the boxplot of the mean noise sensitivity scores over the aircraft noise categories $\left(L_{\mathrm{den}}\right)$. No systematic association is indicated, although-due to large numbers-the statistical test of group differences is significant (F-test: $p<0.05)$. Fig. 8 shows the boxplot of the mean noise sensitivity scores over the airports (country). Significant differences were found (F-test: $p<0.001)$. London-Heathrow subjects were found to be the most noise sensitive, Amsterdam-Schiphol and Stockholm-Arlanda/Bromma subjects were found to be the least noise sensitive.

More important with respect to possible selection bias are within airport comparisons over exposure categories. Within airport analyses did not revea significant trend relationships or group differences between the aircraft noise level $\left(L_{\mathrm{den}}\right)$ and mean noise sensitivity scores-with one exception: In Milan-Malpensa a steady increase of noise sensitivity with increasing noise level was found $(p<0.001)$. This may be an indicator of possible selection bias, presuming that noise sensitivity should be independently distributed over the noise categories within each country. Similarly, mean age and employment status (currently employed) differed between countries. However, no significant trends with aircraft noise were found within countries for age, employment status and gender-again with one exception: In Athens the proportion of females decreased with increasing noise level. All in all, these analyses as well as the non-responder analyses suggest that selection bias is not very likely in the pooled sample when the Athens and Milan airports are excluded.

A pooled exposure-response of the association between noise level and noise annoyance associations between noise level and annoyance were therefore also

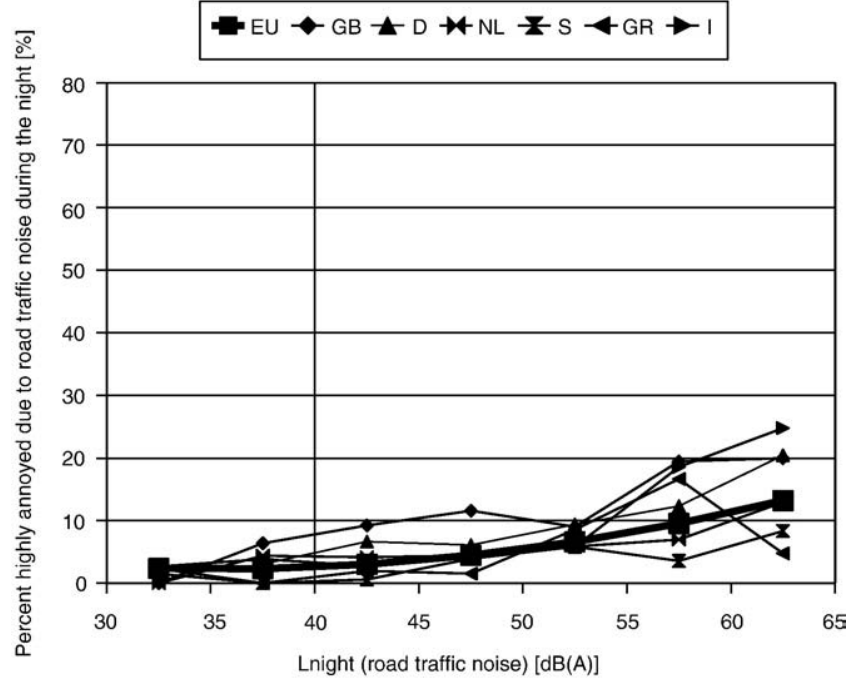

Fig. 4. Relationships between road traffic noise ( $L_{\text {night }}$-road) and annoyance due to road traffic noise during the night (EU and country-specific curves). Note: The EU curve is defined for noise levels from 40 to $70 \mathrm{~dB}(\mathrm{~A})$. 


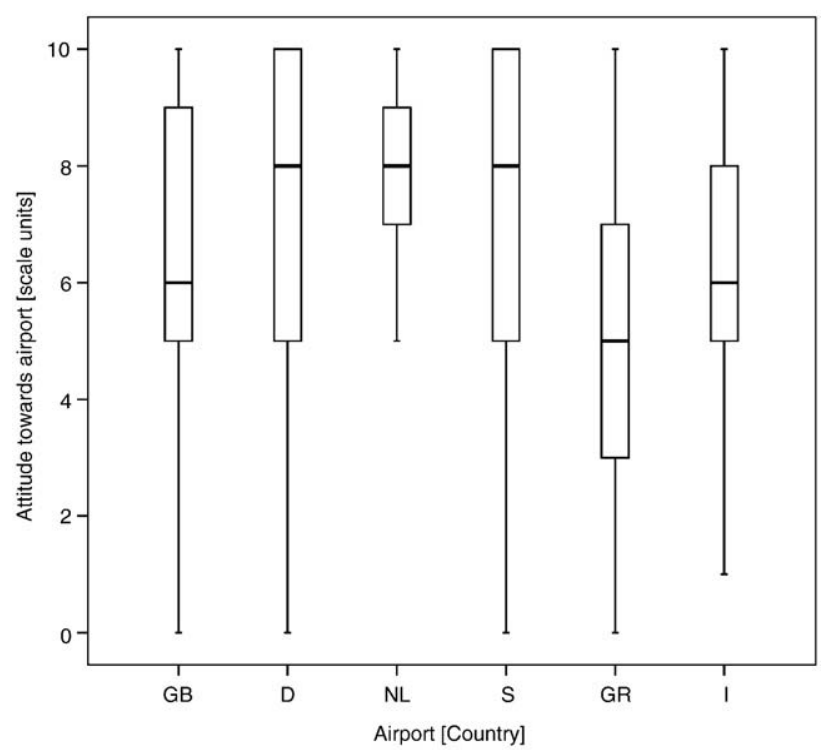

Fig. 5. Boxplot, attitude towards the airport by airport (country) for the reference group of aircraft noise exposure $\left(L_{\mathrm{den}}<45 \mathrm{~dB}(\mathrm{~A})\right)$.

calculated for the reduced sample when these two countries were excluded. The results are shown in Figs. 9 and 10 for daytime annoyance and in Figs. 11 and 12 for night-time sleep disturbance. 95\% confidence intervals are shown for the HYENA curves. Regarding road traffic noise the exclusion changed the result only a little, moving the HYENA curve closer to the EU curve. With respect to aircraft noise the HYENA annoyance curve also moves closer to the EU curve when the two countries are excluded. However HYENA subjects were still much more annoyed by aircraft noise than predicted from the EU curve.

With respect to the annoyance during the day, the HYENA data suggest for aircraft noise levels $\left(L_{\mathrm{den}}\right)$ between 50 and $70 \mathrm{~dB}(\mathrm{~A})$ an approximately " $5-7 \mathrm{~dB}(\mathrm{~A})$ higher annoyance" in the exposed population than predicted by the respective EU annoyance curve. In other words: around 2004 the middle-aged subjects were at a $7 \mathrm{~dB}(\mathrm{~A})$ lower noise exposure as 'highly annoyed' as predicted by noise levels of the corresponding EU curve (European Commission Working Group on Dose-Effect Relations, 2002). With respect to annoyance during the night, for aircraft noise levels $\left(L_{\mathrm{den}}\right)$ between $=40$ and $60 \mathrm{~dB}(\mathrm{~A})$ an even larger difference was found compared with the EU curve for (subjective) sleep disturbance (European Commission Working Group on Health and Socio-Economic Aspects, 2004). No major deviations were found with respect to road traffic noise for the similar comparisons.

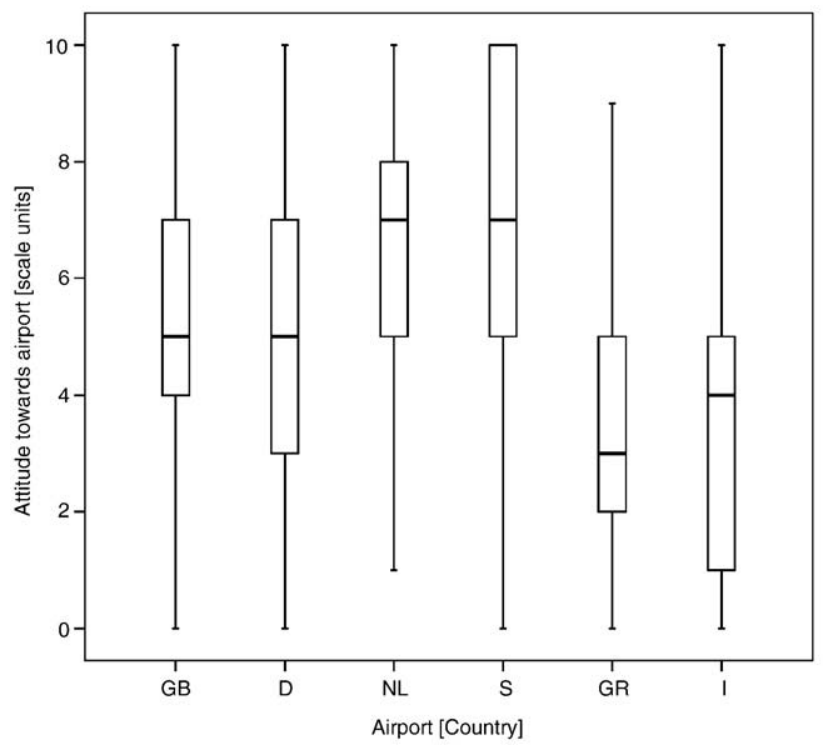

Fig. 6. Boxplot, attitude towards the airport by airport (country) for the two highest groups of aircraft noise exposure exposure $\left(L_{\mathrm{den}} \geq 60 \mathrm{~dB}(\mathrm{~A})\right)$.

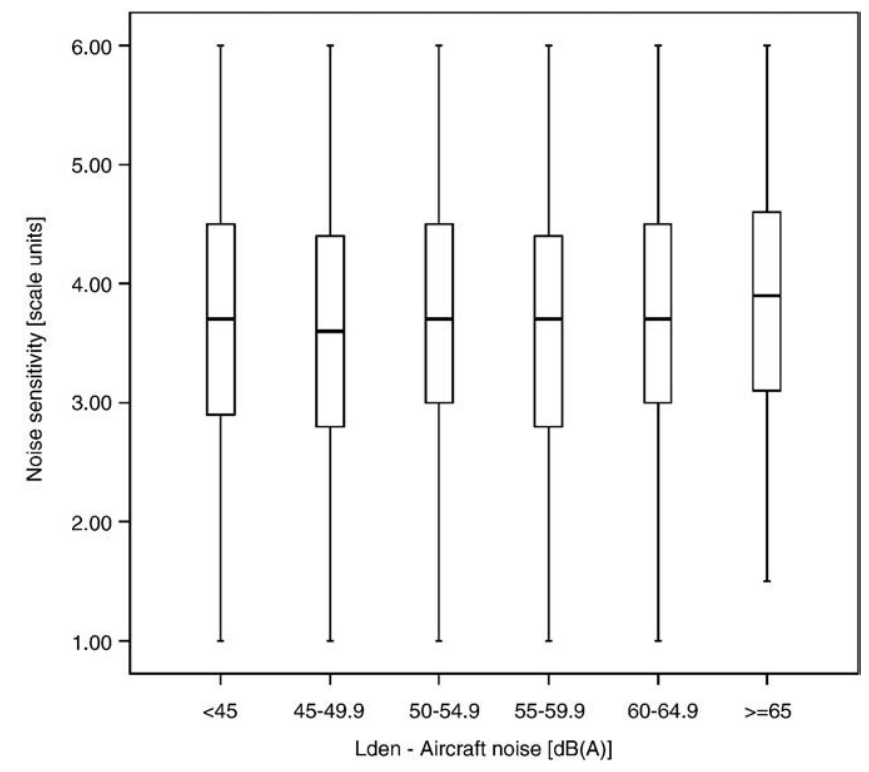

Fig. 7. Boxplot, noise sensitivity by aircraft noise level $\left(L_{\mathrm{den}}\right)$.

\section{Discussion}

Noise annoyance is a multi-factorial concept (Guski et al., 1999; van Kempen and van Kamp, 2005). It summarizes all negative feelings that subjects attribute to a noise source. The sound level only partly explains the variance of the annoyance in empirical studies. The general findings of the HYENA study is that the perception towards aircraft noise of the population that live in the vicinity of major airports in Europe has changed compared to older studies, which are represented by the EU curves for the prediction of noise annoyance (so-called "Miedema curves"). The results, in this respect, support the findings of other studies that were published in the more recent years (Brooker, 2008; Guski, 2003, 2004; Kastka et al., 1995; van Kempen and van Kamp, 2005; Le Masurier et al., 2007; Schreckenberg and Meis, 2006, 2007; Wirth et al., 2005a).

In the HYENA study we assessed the annoyance during the day and the annoyance during the night separately. We did not assess the overall annoyance (day + night), to which the EU prediction curve for

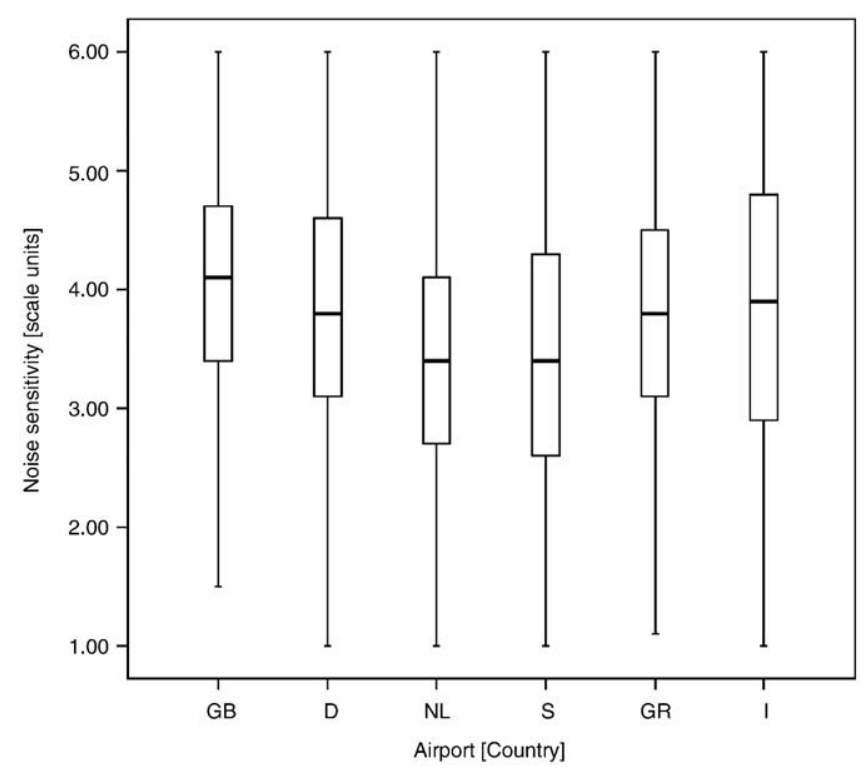

Fig. 8. Boxplot, noise sensitivity by airport (country). 


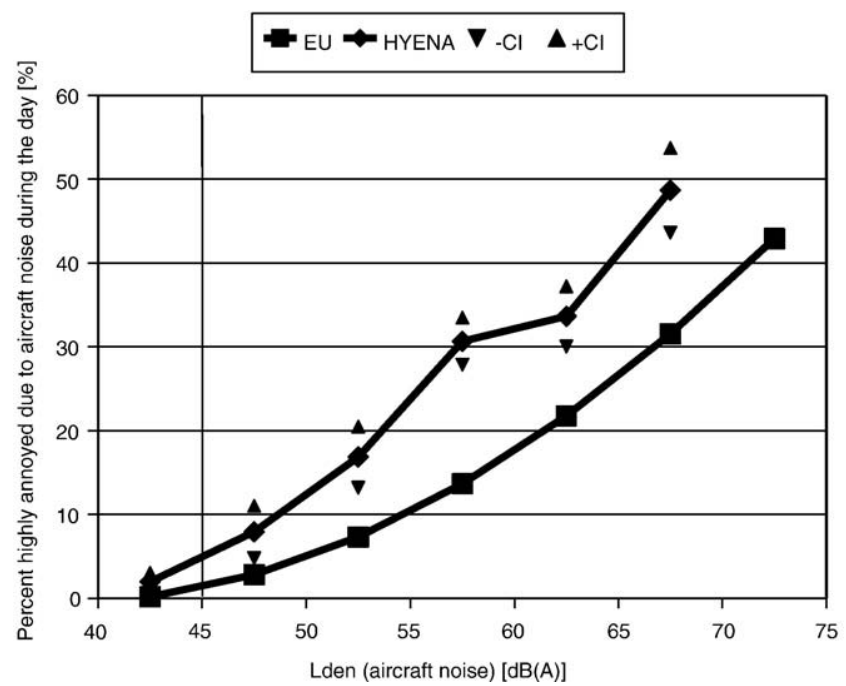

Fig. 9. Relationships between aircraft noise ( $L_{\mathrm{den}}$-air) and annoyance due to aircraft noise during the day (EU curve and HYENA curve (Athens and Milan excluded)). Note: The EU curve is defined for noise levels from 45 to $75 \mathrm{~dB}(\mathrm{~A})$.

$L_{\text {den }}$ refers. When comparing the HYENA curve for annoyance during the day with the EU curve for overall annoyance, we assumed that the overall annoyance (day + night) is mostly determined by the annoyance during the daytime. Comparative studies have shown that with respect to road traffic noise there is no difference between day and night annoyance when the average noise level $\left(L_{\mathrm{eq}}\right)$ is the same (Hoeger et al., 2002). With respect to aircraft noise, higher annoyance ratings during the night than during the day were only found for noise levels above $50 \mathrm{~dB}(\mathrm{~A})$ (Hoeger et al., 2002). The studies carried out around the Zurich airport showed that the general annoyance due to aircraft noise is determined by the outdoor noise exposure in front of the house and less by the indoor noise exposure (Brink et al., 2006).

$L_{\mathrm{den}}$ in the HYENA study, in this context, is understood as a noise indicator of the exposure during the day. This seems reasonable since no distinction is made in the Environmental Noise Directive (END) (Directive 2002/49/EC, 2002) with respect to the exposed side. All determinants ( $L_{\text {day, } 12 \mathrm{~h}}, L_{\text {evening, } 4 \mathrm{~h}}, L_{\text {night, } 8 \mathrm{~h}}$ ) refer to the same most exposed façade, using weighing factors $(+5 \mathrm{~dB}(\mathrm{~A})$ for

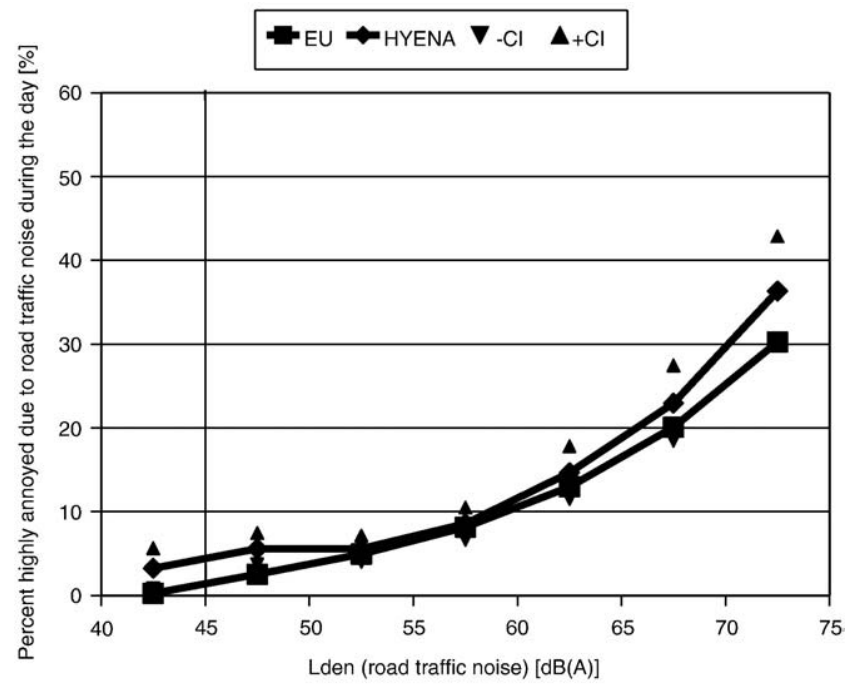

Fig. 10. Relationships between road traffic noise ( $L_{\mathrm{den}}$-road) and annoyance due to road traffic noise during the day (EU curve and HYENA curve (Athens and Milan excluded)). Note: The EU curve is defined for noise levels from 45 to $75 \mathrm{~dB}(\mathrm{~A})$.

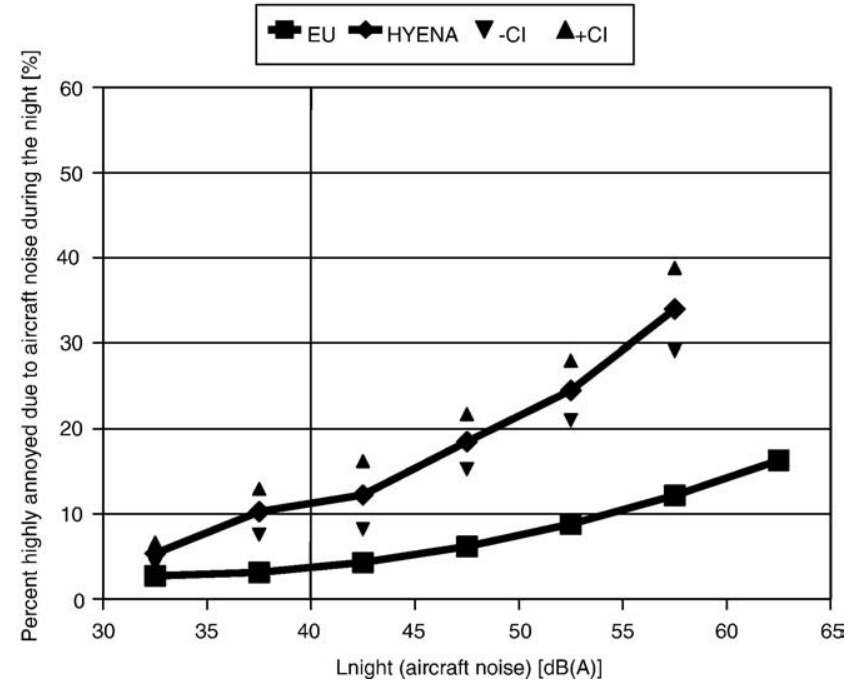

Fig. 11. Relationships between aircraft noise ( $L_{\text {night }}$-air $)$ and annoyance due to aircraft noise during the night (EU curve and HYENA curve (Athens and Milan excluded)). Note: The EU curve is defined for noise levels from 40 to $70 \mathrm{~dB}(\mathrm{~A})$.

evening, $+10 \mathrm{~dB}(\mathrm{~A})$ for night) for the combined indicator $L_{\mathrm{den}}$, approximately shifting the lower evening and night noise levels to the level of the noise during daytime. In principle, $L_{\text {day, } 16 \mathrm{~h}}$ would be a better indicator than $L_{\text {den }}$ for the daytime exposure, particularly, when considering room orientations. However, $L_{\mathrm{den}}$ was considered in the analyses of the HYENA study to comply with the EU standard curves of annoyance.

$L_{\text {night }}$, on the other hand, was considered as a noise indicator of the exposure during the night. Similarly as with $L_{\mathrm{den}}$, the indicator refers to the most exposed façade, not taking into account the location of rooms, particularly, the bedroom. This implies the same degree of exposure misclassification for both, the HYENA study and the EU standard curve of sleep disturbance. However, in the HYENA study the questioning was made with respect to 'annoyance during the night'not explicitly subjective 'sleep disturbance', as the respective EU curve does. When comparing the HYENA curves with the EU curves, we assumed that annoyance during the night reflects sleep disturbance.

Whatever limitations or reservations one could have with respect to the use of $L_{\mathrm{den}}$ for daytime noise exposure or annoyance during the

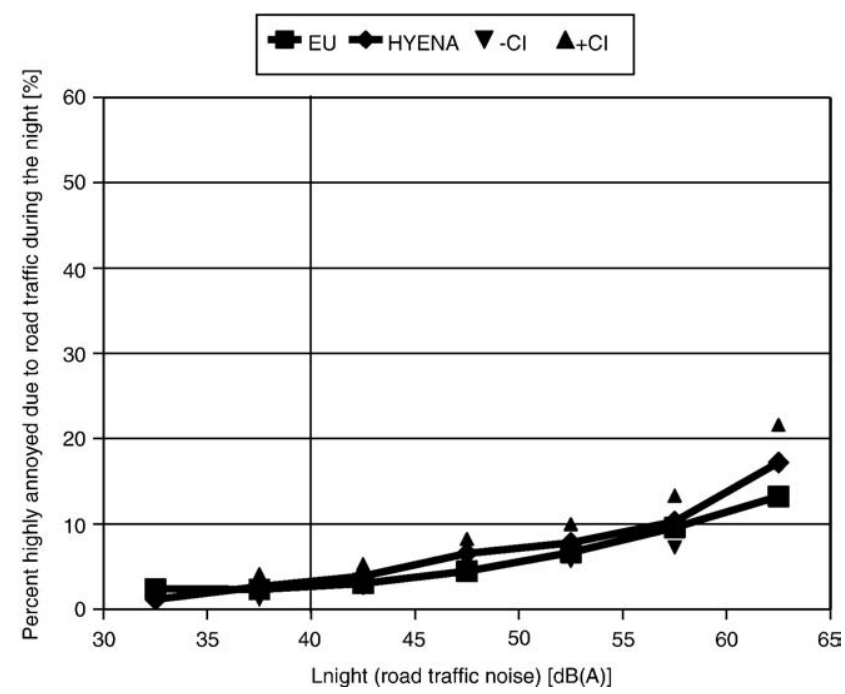

Fig. 12. Relationships between road traffic noise ( $L_{\text {night }}$-road) and annoyance due to road traffic noise during the night (EU curve, and HYENA curve (Athens and Milan excluded)). Note: The EU curve is defined for noise levels from 40 to $70 \mathrm{~dB}(\mathrm{~A})$. 
night as a surrogate for sleep disturbance, the results of the HYENA study regarding road traffic noise are fully in agreement with the EU curves for the prediction of noise annoyance and sleep disturbance due to road traffic noise. Our results regarding road traffic noise annoyance confirm the respective EU curves, which are based on older studies. We therefore feel that the approximations we made were reasonable and that no major change in the perception of road traffic noise had taken place over the years. However, with respect to aircraft noise, large derivations from the EU curve were found although the same methods were applied for aircraft and road traffic noise. This relative difference of effect between road and air traffic noise makes us confident enough to conclude that the exposure-response relationship between noise and noise annoyance has changed over the years, and that this is specific to aircraft noise (upwards shift), because the EU curve refers to older studies. To our knowledge, no such relative comparisons have been made before, because it requires individual noise data for aircraft and road noise for the same subjects. A change in people's perception or attitude towards aircraft noise could be one explanation of the findings.

Our results may not be fully comparable to the EU curve, because in the HYENA study annoyance was assessed in the limited age range of 45-70 year old subjects. In meta-analyses that comprised a much wider age range, an inverse U-shaped association was found between age and annoyance. The age group 30 to 50 years was most annoyed by aircraft noise. Annoyance reactions were found to be lower in younger and older subjects (Miedema et al., 2000). In the HYENA study, age was negatively associated with annoyance by trend, which is in line with the findings and results from other countries (Michaud et al., 2005). This suggests that annoyance was more likely to be underestimated than overestimated in our study compared to the generalised EU curve that includes all ages.

It has been suggested that also annoyance reactions may be stronger in some European regions than predicted by the EU curve due to cultural or climate conditions. Norwegians reacted stronger to road traffic noise than predicted by the EU curve (Klaeboe et al., 2004). We could not confirm this finding within our Swedish Scandinavian sample. At the first glance, one would expect lower annoyance reaction in countries where people have to close their windows more due to the cold weather. On the other hand, the expectations for a quiet environment may be higher (Ouis, 2002), particularly, during the short season of the year when people spend more time outdoors. Cultural differences can also play a role. Spatial differences of the annoyance over Europe were found in comparative studies indicating that southern Europeans were less annoyed by road traffic noise than northern Europeans (Diaz et al., 2001). Surprisingly, the opposite was found with respect to aircraft noise (Diaz et al., 2001). It was suggested that people from southern Europe might be more annoyed by aircraft noise than people from northern and central Europe if the noise level $L_{\mathrm{eq}, 24 \mathrm{~h}}$ is below $65 \mathrm{~dB}(\mathrm{~A})$.

An attempt was made to quantify the deviation of the annoyance of the HYENA sample from the EU curve. The airport-specific annoyance curves gave some indication that the very high annoyance scoring of the Athens and Milan sample could have been due to an overshooting of annoyance reporting (over-reaction)) because of recent changes in airport operations (Bröer and Wirth, 2004; Brown and van Kamp, 2008; Guski, 2004; Hatfield et al., 2002; Job, 1988b). Steady-state conditions may not have been reached. The new Athens airport only went into operation a few years before the study was carried out and the Milan airport had only just been changed from a small airport being used for local traffic to a major international commercial airport. Furthermore, based on the assessment of noise sensitivity, there was some indication that a certain degree of selection bias (more noise sensitive subjects in more aircraft noise exposed areas) might have been present in the Milan sample. We therefore excluded these two airports from the pooled analyses. Whereas the exposure-response curves of the EU position paper for the prediction of annoyance due to road traffic noise were well reproduced, there were marked derivations from the respective aircraft noise curves, indicating an increase of aircraft noise annoyance over the years. A 5 to $7 \mathrm{~dB}(\mathrm{~A})$ lower aircraft noise level (within the range of $L_{\mathrm{den}}=50$ to $70 \mathrm{~dB}(\mathrm{~A})$ ) caused the same annoyance in northern and central European subjects as indicated by the exposure-response curve used in the European Community for the prediction of noise annoyance (European Commission Working Group on Dose-Effect Relations, 2002).

Based on the HYENA data we cannot give any explanation for the possible effect of an increase of annoyance reactions due to aircraft noise over the years. An increase in the number of events each of lower maximum noise level due to quieter aircraft (causing the same $L_{\mathrm{den}}$ ) could be a reason for this (Bröer and Wirth, 2004; Quehl and Basner, 2006). Changes in non-acoustical factors moderating the annoyance could play a role. The issue has been discussed in the broader context of the "risk society theory", including aspects of fear, trust and control, and the incapacity of the industrial society to control pollution and prevent severe accidents (Bröer, 2007; Wirth et al., 2005b). "Attitude towards the airport" varied between our study samples even in the non-exposed reference group $\left(L_{\mathrm{den}}<45 \mathrm{~dB}(\mathrm{~A})\right)$. It co-varied with the annoyance. However, the cause-effect direction is not clear. Scientific reporting about risks and adverse effects of noise in the media could have affected people's opinion. However, our data does not suggest a shift towards higher noise annoyance, in general, because no higher annoyance than predicted by the EU curve was found for road traffic noise.

\section{Conclusion}

Our data indicates that annoyance due to aircraft noise has increased throughout the recent years, and that the current EU prediction curve for aircraft noise annoyance should be modified. No respective changes were found with respect to annoyance due to road traffic noise.

\section{Acknowledgements}

The authors would like to thank the Hyena study team and the participants for their time and effort. The authors would also like to thank the Aviation Administrations and the Road Administrations in each of the participating countries for their contribution to the exposure assessment.

The study was funded by grants from the European Commission (Directorate General Research) Quality of Life and Management of Living Resources, Key Action 4 Environment and Health (grant QLRT2001-02501).

Members of the HYENA study team:

Töres Theorell, Gabriele Wölke, Ingeburg Seiffert, Birgitta Ohlander, Eva Thunberg, Bertolomé de la Torre, Jessica Kwekkeboom, Pauline Savigny, Joy Read, Yvonne Tan, Yousouf Soogun, Yannis Zahos, Venetia Velonakis, Ageliki Athanasopoulou, Anna Armitano, Domenico Bonarrigo, Federica Mathis, Raffaella Martinez, Silvana Barcellini, Mara Lambertini, Laura Cianfrocca, Clara Tovo, Maria Palma Ceriani.

\section{References}

ANSI S12.9. US Standard: Quantities and procedures for description and measurement of environmental sound-Part 4: Noise assessment and prediction of long-term community response; 2003.

Bendtsen $\mathrm{H}$. The Nordic prediction method for road traffic noise. Sci Total Environ 1999;235:331-8

Bite M, Bite PZ. Zusammenhang zwischen den Straßenverkehrslärmindizes LAeq(0622) und LAeq(22-06) sowie Lden. Zeitschrift für Lärmbekämpfung. 2004;51:27-8. Brink, M. Wirth, K· Rometsch, R.Schierz, C. Lärmstudie 2000-Zusammenfassung Teil 1: Die Belästigung durch Fluglärm im Umfeld des Flughafens Zürich (Bevölkerungsbefragungen der Jahre 2001 und 2003); Teil 2: Der Einfluss von abendlichem und morgendlichem Fluglärm auf Belästigung, Befindlichkeit und Schlafqualität von 
Flughafenanwohnern (Feldstudie). Zurich: Swiss Federal Institute of Technology Zurich; 2006.

Bröer C. Aircraft noise and risk politics. Health, Risk Soc 2007;9:37-52.

Bröer C, Wirth K. Mehr Belästigung bei gleichem Pegel. Zeitschrift für Lärmbekämpfung. 2004:51:118-21.

Brooker P. Finding a good aircraft noise annoyance curve. Acoust Bull 2008;33:36-40.

Brooker P. Do people react more strongly to aircraft noise today than in the past? Appl Acoust 2009;70:747-52.

Brown, L; van Kamp, I. Estimating the magnitude of the change effect. In: Griefahn, B., ed. Proceedings of the 9th Congress of the International Commission on the Biological Effects of Noise, Mashantucket, Foxwoods, July 21-25, 2008: ICBEN; 2008.

Bundesministerium für Verkehr (Ministry of Transport). Richtlinien für den Lärmschutz an Straßen (RLS90)-Guidelines for noise protection on streets (RLS90). Bonn: Bundesministerium für Verkehr; 1990.

Department for Transport and Welsh Office. Calculation of road traffic noise. London: HMSO; 1988.

Diaz J, Ekelund M, Gothe R, Huber M, Jordan A, Kallischnigg G, et al. Traffic noise pollution. "Similarities and differences between European regions"-a state of the art review. Luxembourg: The European Commission, Directorate-General Health and Consumer Protection; 2001.

Directive 2002/49/EC. Directive of the European Parliament and of the Council of 25 June 2002 relating to the assessment and management of environmental noise. Official Journal of the European Communities. L 189:12-25; 2002.

European Civil Aviation Conference. Report on standard method of computing noise contours around civil airports. 2nd ed., doc 29. Strasbourg: Twenty First Plenary Session of ECAC; 1997.

European Commission Working Group Assessment of Exposure to Noise (WG-AEN). Good practice guide for strategic noise mapping and the production of associated data on noise exposure, Version 2, 13 January 2006. Position paper, final draft, WGAEN 0162003doc. Brussels: European Commission; 2006.

European Commission Working Group on Dose-Effect Relations. Position paper on dose response relationships between transportation noise and annoyance. Luxembourg: Office for Official Publications of the European Communities; 2002.

European Commission Working Group on Health and Socio-Economic Aspects. Position paper on dose-effect relationships for night time noise. Brussels: European Commission; 2004.

Fields JM. Effect of personal and situational variables on noise annoyance in residential areas. J Acoust Soc Am 1993;93:2753-63.

Fields JM, Walker JG. Comparing the relationships between noise level and annoyance in different surveys: a railway noise vs. aircraft and road traffic comparison. J Sound Vib 1982;81:51-80.

Fields JM, de Jong RG, Gjestland T, Flindell IH, Job RFS, Kurra S, et al. Standardized general-purpose noise reaction questions for community noise surveys: research and recommendation. J Sound Vib 2001;242:641-79.

Franssen EAM, Wiechen CMAG, Nagelkerke NJD, Lebret E. Aircraft noise around a large international airport and its impact on general health and medication use. Occup Environ Med 2004;61:405-13.

Gjestland, T. Research on community response to noise-in the last five years. In: Griefahn, B., ed. Proceedings of the 9th Congress of the International Commission on the Biological Effects of Noise, Mashantucket, Foxwoods, July 21-25, 2008: ICBEN; 2008.

Gulding JM, Olmstead JR, Fleming GG. Integrated noise model (INM) version 6.0 user's guide. Report No. FAA-AEE-99-03. Washington D. C: Department of Transportation, Federal Aviation Administration; 2002.

Guski R. Personal and social variables as co-determinants of noise annoyance. Noise Health 1999;1(3):45-56.

Guski R. Neuer Fluglärm gleich alter Fluglärm? Zeitschrift für Lärmbekämpfung 2003;50.

Guski R. How to forecast community annoyance in planning noisy facilities. Noise Health 2004;6(22):59-64.

Guski R, Felscher-Suhr U, Schuemer R. The concept of noise annoyance: how international experts see it. J Sound Vib 1999;223:513-27.

Hatfield, J.; Job, S.; Faunce, G.; Carter, N.; Peploe, P.; Taylor, R., et al. The effect of changed levels at Sydney Airport on health outcomes II: The role of anticipation and reaction. Proceedings of Forum Acousticum 2002 in Seville, Paper No. NOI-05-006. Madrid: Sociedad Espanola de Acustica; 2002.

Hoeger R, Schreckenberg D, Felscher-Suhr U, Griefahn B. Night-time noise annoyance: state of the art. Noise \& Health 2002;4(15):19-25.

ISO 1996/1. Acoustics-description, measurement and assessment of environmental noise-Part 1: basic quantities and assessment procedures. Geneva: ISO; 2003.

Jakovljevic B, Paunovic K, Belojevic G. Road traffic noise and factors influencing noise annoyance in an urban population. Environ Int 2009;35:552-6.

Jarup L. Hypertension and exposure to noise near airports. Final report and annex prepared for the European Commission DG Research. London: Imperial College London; 2007.

Jarup L, Dudley M-L, Babisch W, Houthuijs D, Swart W, Pershagen G, et al. Hypertension and exposure to noise near airports (HYENA): study design and noise exposure assessment. Environ Health Perspect 2005;113:1473-8.

Jarup L, Babisch W, Houthuijs D, Pershagen G, Katsouyanni K, Cadum E, et al. Hypertension and exposure to noise near airports-the HYENA study. Environ Health Perspect 2008;116:329-33.

Job RFS. Community response to noise: a review of factors influencing the relationship between noise exposure and reaction. J Acoust Soc Am 1988a;83:991-1001.

Job RFS. Over-reaction to changes in noise exposure: the possible effect of attitude. J Sound Vib 1988b;126:550-2.
Job RFS. Impact and potential use of attitude and other modifying variables in reducing community reaction to noise. Transport Research Record 1991;1312:109-15.

Job RFS. Noise sensitivity as a factor influencing human reaction to noise. Noise \& Health 1999;1(3):57-68.

Job RFS, Hatfield J. Community reaction to noise. Acoust Aust 1998;26:35-9.

Kastka, J.; Borsch-Galetke, E.; Guski, R.; Krauth, J.; Paulsen, R.; Schuemer, R., et al Longitudinal study on aircraft noise. Effects at Düsseldorf Airport 1981-1993. ICA95, Proceedings of the 15th International Congress on Acoustics. Trondheim; 1995.

Klaeboe R, Amundsen AH, Fyhri A, Solberg S. Road traffic noise-the relationship between noise exposure and noise annoyance in Norway. Appl Acoust 2004;65:893-912.

Kroesen M, Molin EJE, van Wee B. Testing a theory of aircraft noise annoyance: a structural equation analysis. J Acoust Soc Am 2008;123:4250-60.

Kryter KD. Community annoyance from aircraft and ground vehicle noise. J Acoust Soc Am 1982;72:1222-42.

Kryter KD. Response of K. D. Kryter to modified comments by T. J. Schultz on K. D. Kryter's paper, "Community annoyance from aircraft and ground vehicle noise" [J. Acoust. Soc. Am 72, 1243-1252]. J Acoust Soc Am 1983;73:1066-8.

Le Masurier P, Bates J, Flindell I. ANASE, Attitudes to noise from aviation sources in England. Executive summary. Norwich: Queen's Printer and Controller of HMSO; 2007.

Michaud DS, Keith SE, McMurchy D. Noise annoyance in Canada. Noise \& Health 2005;7 (27):39-47

Miedema, H.M.E.; Borst, H.C. Rating environmental noise on the basis of noise maps within the framework of the EU Environmental Noise Directive. In: I-INCE, ed. Inter-Noise 2007, Proceedings of the 36th International Congress and Exhibition on Noise Control Engineering, Istanbul, Turkey, August 28-31. Istanbul: Turkish Acoustical Society; 2007.

Miedema HME, Oudshoorn CGM. Annoyance from transportation noise: relationships with exposure metrics DNL and DENL and their confidence intervals. Environ Health Perspect 2001;109:409-16.

Miedema HME, Vos H. Exposure-response relationships for transportation noise. J Acoust Soc Am 1998;104:3432-45.

Miedema HME, Vos H. Demographic and attitudinal factors that modify annoyance from transportation noise. J Acoust Soc Am 1999;105:3336-44.

Miedema HME, Vos H. Associations between self-reported sleep disturbance and environmental noise based on reanalyses of pooled data from 24 studies. Behavioral Sleep Medicine 2007;5:1-20.

Miedema HME, Vos H, de Jong RG. Community reaction to aircraft noise: time-of-day penalty and tradeoff between levels of overflights. J Acoust Soc Am 2000;107:3245-53.

Ministry of Housing Spatial Planning and the Environment. Reken- en Meetvoorschrift Wegverkeerslawaai (SRM). Den Haag: Ministry of Housing, The Netherlands; 2002.

Öhrström E, Bjorkman M, Rylander R. Noise annoyance with regard to neurophysiological sensitivity, subjective noise sensitivity and personality variables. Psychol Med 1988;18:605-11.

Ouis D. Annoyance from road traffic noise: a review. J Environ Psychol 2001;21:101-20.

Ouis D. Annoyance caused by exposure to road traffic noise: an update. Noise \& Health 2002;4(15):69-79.

Quehl J, Basner M. Annoyance from nocturnal aircraft noise exposure: laboratory and field-specific dose-response curves. J Environ Psychol 2006;26:127-40.

Schreckenberg D, Meis M. Effects of aircraft noise annoyance and quality of life around Frankfurt Airport. Final abbridged report. Besheim: Regional Dialogue Forum Frankfurt Airport; 2006

Schreckenberg, D.; Meis, M. Noise annoyance around an international airport planned to be extended. In: I-INCE, ed. Inter-Noise 2007, Proceedings of the 36th International Congress and Exhibition on Noise Control Engineering, Istanbul, Turkey, August 2831. Istanbul: Turkish Acoustical Society; 2007.

Schultz TJ. Synthesis of social surveys on noise annoyance. J Acoust Soc Am 1978;64:377-406.

Schultz T]. Comments on K. D. Kryter's paper "Community annoyance from aircraft and ground vehicle noise". J Acoust Soc Am 1982;72:1243-52.

Stansfeld SA. Noise, noise sensitivity and psychiatric disorder: epidemiological and psychophysiological studies. Cambridge: Cambridge University Press; 1992

Stansfeld S, Shine P. Noise sensitivity and psychophysiological responses to noise in the laboratory. In: Vallet M, editor. Noise and Man '93, Proceedings of the 6th International Congress on Noise as a Public Health Problem, Nice. Arcueil Cedex: Institut National de Recherche sur les Transports et leur Sécurité; 1993.

van Kamp, I. Coping with noise and its health consequences. Thesis at University of Groningen. Groningen: STYX; 1990.

van Kamp I, Soames Job RF, Hatfield J, Haines M, Stellato RK, Stansfeld S. The role of noise sensitivity in the noise-response relation: a comparison of three international airport studies. J Acoust Soc Am 2004;116:3471-9.

van Kempen EEMM, van Kamp I. Annoyance from air traffic noise. Possible trends in exposure-response relationships. Report 01/2005 MGO EvK. Bilthoven: RIVM; 2005.

van Kempen EEMM, Staatsen BAM, can Kamp I. Selection and evaluation of exposureeffect-relationships for health impact assessment in the field of noise and health RIVM report No. 630400001/2005. Bilthoven: RIVM; 2005.

Wirth K, Bröer C, Brink M, Schierz C. Changes of noise annoyance in the course of time (in German). Umwelt Forsch Prax 2005a;10:105-11.

Wirth K, Bröer C, Brink M, Schierz C. Veränderung der Lärmbelästigung im zeitlichen Verlauf. Umwelt Forsch Prax 2005b;10:105-11. 